\title{
When Solidarity is Trampled by Religious Sentiment: Outlining Indonesian Muslim Solidarity toward Rohingya Refugees
}

\author{
Siti Aliyuna Pratisti ${ }^{1}$, Taufik Hidayat ${ }^{2}$, Deasy Silvya Sari ${ }^{3}$ \\ ${ }^{1}$ Department of International Relation, Faculty of Social and Political Sciences, Padjadjaran University \\ (email: aliyuna@unpad.ac.id) \\ ${ }^{2}$ Department of International Relation, Faculty of Social and Political Sciences, Padjadjaran University \\ (email: taufik_hidayat@unpad.ac.id) \\ 3Department of International Relation, Faculty of Social and Political Sciences, Padjadjaran University \\ (email: deasy.sylvia@unpad.ac.id)
}

\begin{abstract}
The Rohingya crisis in Myanmar has drawn international attention due to gross violations of human rights, which have occurred in the conflict. This condition forces the Rohingya to flee from conflict areas in the attempt to seek protection from neighbouring countries including Indonesia. To deal with the refugees, the Indonesian government, alongside Muslim organizations, have taken immediate steps in tackling the crisis. However, behind the humanitarian solidarity lays a critical problem related to the religious sentiment toward the Buddhist community in Indonesia. The sentiment that tarnished the humanitarian principles and threatened Indonesian multiculturalism showed the versatile side of identity. To provide a better understanding of identity-based conflict, this article explored how a group's sense of collectivity can easily turn into sentiment. By conducting multiple interviews with the representatives of Muslim Organizations and also collecting secondary data related to the Islam conservative agenda, this paper aimed to outline the paradox of Indonesian Muslim response toward the Rohingya's refugees crisis. Using Ross's theories of identity conflict and using Galtung conception of social conflict, the findings concluded that religious sentiment in Indonesia during the Rohingya's refugee crisis are led by blind fanaticism toward certain religious beliefs that bitterly trample the nation's sense of solidarity.
\end{abstract}

\section{Keywords:}

humanitarian act; religious sentiment; solidarity; the Rohingnya

\section{Introduction}

The humanitarian crisis in Rakhine, which involved the Rohingya minority has had a significant impact not only on Myanmar domestic politics but also on other nations. More than 600,000 ethnic Rohingya people fled into Bangladesh, which became the primary destination for the refugees to seek protection (Martin et al., 2017, p. ii). The rest of the refugees tried to find a more conducive environment in other Asian countries, such as Malaysia and Thailand. In 2015, more than 2,000 Rohingyan were stranded and rescued by the Aceh fishermen in Indonesia (Jati, 2017, p. 18). A large number of refugees and the gross violations of human rights that caused many Rohingya to lose their lives, homes, freedom and dignity, have prompted international communities to initiate necessary measures in assisting the victims. The humanitarian crisis also received coverage from international media, which pressured the Myanmar government to resolve the conflict. Despite the pressure from the international 
community, the Myanmar government has not shown any positive response to this demand (Milton, 2017, p. 3). Association of Southeast Asian Nation (ASEAN) is expected to play an active role as mediator. However, ASEAN undergo major obstacles in dealing with the Rohingya issue in consideration to the principle of non-intervention that is still firmly held by its members (Arendshorst, 2009, p. 103). In this stagnant condition, transnational communities pave the way for humanitarian relief and bridge the gap for humanitarian diplomacy with Myanmar. This involvement of transnational communities creates a new level of attention to the Rohingya conflict with the widespread of solidarity voiced by Muslim societies in various countries (Hidayat, Sari, \& Pratisti, 2017, p. 404). In Southeast Asia, protests against Myanmar repressive policy towards Rohingya had been distinctly voiced by a number of civil society movements. They initiated the Southeast Asia Humanitarian Mission (SEAHUM), a committee established to respond to the Rohingya crisis (Hidayat et al., 2017, p. 404).

Despite the international efforts, the humanitarian crisis still ongoing in Myanmar has led to another wave of refugees in early 2018 (The Jakarta Post, 2018). Referring to the historical complexity, ${ }^{1}$ conflict in Myanmar is rooted in the country's struggle over political

\footnotetext{
1 Myanmar's territory divided into seven states named according to the majority ethnic population and seven regions inhabited by a majority ethnic Burmese. Myanmar's population in 2011 ranged from 48,337 million. The ethnic composition of the population according to the Central Intelligence Agency (2013) is Burmese ethnic 68\%, Shan 9\%, Karen 7\%, Rakhine 4\%, China $3 \%$, Indian $2 \%$, Mon $2 \%$, and others $5 \%$. On the other hand, the religious composition of the population includes $89 \%$ of Buddhists, $4 \%$ of Islam, and the rests are Christians and other beliefs (Habibollahi, McLean, \& Diker 2013). Khin (2005) stated that Muslims in Burma constitute a significant minority accounting for about $13 \%$ of the Buddhist-dominated country (p. 176). The diversity in the Burmese Muslim population has its effect in their respective dealings with the Buddhist majority. Each group has very different relationships with the Buddhist majority and with each other.
}

and economic control between two contending groups, the military Junta and the National Democratic League. Rakhine, the province where the atrocities took place, is a state in Myanmar with the highest number of Muslims; about $45 \%$ of the total Muslims in Myanmar (Kyaw, Taylor, \& Tin, 2005). However, this conflict has evolved into ethnic and religious conflict since the parties involved are categorized based on the religious group of the Buddhist majority and the Muslim minorities (Raharjo, 2015, p. 35). This brought a significant impact to the nature of conflict by shifting it into identity politics. The Rohingya case reached the realm of transboundary conflict as it triggered a strong reaction from international Muslim communities. Indonesia, the largest Muslim country in the world, is also affected by the conflict. In Indonesia, Muslim communities from international non-state organizations to individual movements have continued to provide humanitarian assistance for the Rohingya. The Muslim communities in Indonesia demonstrated great sympathy to the Rohingnya since the country has also experienced its dark history of identity conflict in Ambon. This sympathy indicates that identity is a strong factor to drive solidarity. However, sympathy also can trigger social conflict-such a case happened in 2017 when humanitarian solidarity for the Rohingya was trampled by religious sentiment toward Buddhists in Indonesia.

The sentiment hit a critical point in 2017 when the Islamic Defenders Front (Front Pembela Islam, FPI) intended to destroy Borobudur as a symbolic action for their resentment toward the Myanmar government (BBC, 2017). They also accused Buddhists of Indonesia of being involved in supporting violence towards the Rohingya (Hodges \& Rayda, 2017). This phenomenon sets a crucial remark in the outline of Indonesian Muslims' response toward the Rohingya refugees crisis. As identity cohesiveness worked as a driving force for 
Indonesian Muslims to assist the Rohingya, the act should be based on the principle of humanity rather than blind fanaticism. However, the religious sentiment has demeaned the Muslim solidarity towards the Rohingya and threatened the multiculturalism of Indonesia. Therefore, this article offers an outline of Indonesian Muslim responses toward the Rohingya crises by answering two basic questions: What drives the massive humanitarian solidarity of Indonesian Muslims toward the Rohingya refugees? And why is there the other side of the coin - a destructive side of identity that has tarnished the sincere humanitarian action of the Indonesian Muslims? The act of scapegoating a specific religious is not only contradictory to the humanitarian principles but also threatens the unity of Indonesia. And lastly, the article also depicts how Indonesian Muslims dealt with the sentiment.

\section{Literature Review}

Studies of group identity found their basis in "collective sense," a perception of an individual's sense of belonging to an "ingroup" constructed from the group interaction with another (Luhtanen, 1992). In the era of globalization, the collective sense is no longer bound to the state territory, as dissemination and interaction through various transborder becomes more visible. It may also function as the basis of solidarity that can bring positive values such as humanitarianism. Kastoriano (2000) mentioned that the idea of a transnational society refers to "a community consist of individuals or groups formed in different national societies, and acting on the basis of common interests and references (which may be territorial, religious or linguistic), and networks used to strengthen their solidarity outside boundaries of the state." But on the other hand, the collective sense also bears a burden as the source of the most violent social conflict recorded in history, including genocide and ethnoreligious conflict, as the others are often perceived as threat (Ross, 2007). Another basis for identity studies is the emphasis on structural approaches to analyze the relationships between the groups involved (Styker \& Burke, 2000). The unequal distribution of political and economic resources repeatedly turns into the cause of disputes among identity groups, which lead to violent conflict. There are several cases related to the structural inequalities; for example, the unequal distribution of land that led to genocide in Darfur, Sudan (Hagan \& Rymon-Richmond, 2009), and the separatist movements in Aceh caused by disparities in economic distribution. In both cases, the imbalance of inter-group relations triggered the perception of threats from one group to another.

Intertwined with cultural narratives and emotional bonds constructed in society, the perception of threats towards other groups played the basic formation of identity conflicts (Wolff, 2006, p. 38). The emotional dimension adds to the complexity and amplifies the particular character of identity conflicts. The Rohingya crisis bears a similar complexity. It evolves from a conflict of political repression and unequal economic distribution into a conflict between identities, which shapes the mindset of society, both domestically and internationally. Wilson (2008) explains that emotional factors are most likely to motivate individuals to commit violence in identity conflict. While analysts often emphasize one of two types of motivation and rational calculation of interests (utility maximization or instrumentalism), proponents of rational choice recognize the role of emotion in conflict. Wilson also stated that it is important to analyze conflicts at four distinct levels: individual, subcommunal, communal, and structural levels, as an attempt to understand the agendas, social construction, and human interaction which constitutes violence.

Galtung (1958) defines social conflict as a conflict involving people or groups, rooted in 
the lack of common ground or common interest between parties. But suggesting identity conflict solely as a matter of different interest simply lightens its intricacy. Therefore, Coser (as cited in Zeitlin, 1998) redefines the concept of social identity conflict as a competition resulted from an attempt of different groups to gain recognition of certain values and status. Thus, interest in identity conflict is strongly related to the values and principles held by the disputing group. But it does not mean Galtung's ideas of social conflict lost its relevancy, since he provided an understanding of the level of conflict that can occur either on a personal or within a structural level (group or country). Identity has a wide range of definitions including the cultural, social and political values attached to a person or a group. It is functions to create a collective and common experience of cultural values shared among a diverse range of people. Therefore, identity conflict is concerned with group judgments toward other groups and their motives (Ross, 2002). It is also related to the views, ideas or ideologies held by a person or group (Ross, 2007).

The evolution of the Rohingya conflict in Myanmar has bent towards the scope of identity conflict. Originally rooted in the problem of political and economic disparities, it turned into a violent identity conflict. The condition was aggravated by the closed social structure in Myanmar, which intensifies perception of threat among ethnic and religious groups. The tension between groups in Myanmar is capable of producing intergroup conflicts. But the closed system and scarce economic resource alone are insufficient to ignite such conflict. Seul (1999) argues that identity competition is a necessary condition to the eruption of intergroup conflict (p. 563). Therefore, identity plays a vital role in triggering social conflict. Seul adds that religion has a more powerful ability than another symbol of identity, to shift the dynamics of group relations. It can produce either constructive stability or rapid escalation of intergroup conflict.

Conflicts of ethnic groups are caused by either material or social dynamics factors. The perception of threat fuels conflict between ethnic and other identity groups (Kyaw et al., 2005). The absence of effective government typically becomes the main force to trigger identity conflicts. Suel (1999) also states that despite the powerful capability to escalate the conflict, religion is not the cause of conflict. Rather, it provides the most secure basis for maintenance of an identity bound and frequently supplies the fault line along which intergroup identity and resource competition occur. Nonetheless, it is difficult to maintain a stable inter-religious group relations without an effective system and social cohesion. The Arakan state, for example, is dealing with social cleavage that has lasted for decades, setting up the Buddhist majority and Muslim minorities in a hostile relation. Since the intergroup relations are constructed on the basis of religion, it leads the conflict to the spiral dynamics of ethnic-religious conflicts.

To understand religious conflict, Basedau et al. (2011) defines the conflict into two formations. First, the substantial formation in which the religious traits become the center of discrepancies. Second, the functional formation in which religious traits become an instrument for group identification ( $\mathrm{p}$. 26). The functional conflict may also evolve into the formation of religious polarization, discrimination, and sentiments. Furthermore, Fox (as cited in Lindberg, 2008), using t-test statistics in analyzing religious conflicts, concludes that conflicts between religions tends to result in more deaths and higher intensity compared to conflicts without religious affiliation. Linberg's analysis is in line with the research on the settlement of religious conflict completed by Svensson (as cited in Gelfand, 2004), which draws an alarming conclusion that it is unlikely for religious conflict to be 
resolved by negotiations. Emotion and loyalty are factors that greatly affect the dynamics of religious conflict. Within this context, it is crucial to understand the dynamics between the Buddhists and the Muslims of Rakhine to understand the Rohingya crisis.

The presence of emotional feeling on identity conflict tends to escalate the tension and then shape misperceptions among groups. As a result of the emotional manifestation, hatred is also embodied in identity conflicts (Ross, 2007). The range of violent identity conflicts spans from discrimination, exploitation, intercommunity tensions, clashes between groups of different identities, to its most brutal form: the genocide. There are also subtle conflicts of identity that exist within the society; for example, stereotyping. However, if the tension between ethnics is omitted, it can lead to a danger of misperception. Many identity conflicts followed these dynamics: it was never a spontaneous conflict; rather it culminated in the history of groups relation. Identity conflicts can also stem from "a wounded collective pride" (Luhtanen \& Crocker, 1992). The "pride" refers to the sense of ownership of certain status of the in-group (us) which was contradicted by the outsider group (them). The sense of pride also drives individuals to engage emotionally. In other words, collective pride holds significant values to the identity construction. For example, the repression over the Rohingya in Myanmar provoked a strong reaction from Muslims around the world. This illustrates how the diffusion of emotional feeling toward Muslims in Rohingya has been shared beyond the borders of nationality.

The Muslim community has taken various actions in response to the Rohingyas crisis-from transnational networks to small communities in society, solidarity towards the Rohingya had been expressed by protesting Myanmar policy to humanitarian action. However, in Indonesia, the protests turned into a strange direction. In the midst of solidarity towards Rohingya, there had been few elements of Muslim communities who spread out the issue of religious sentiments. There were Muslim communities insisting their view over the Rohingya crisis and emphasizing the repression of Muslims by the Buddhist majority of Rakhine. In result, Buddhists in Indonesia are subjected to religious sentiments. The sentiment is the result of communities attachment. Seul (1999) explains that religious communities share meaning systems (belonging) and affirmation (as a basis for self-esteem) (p. 599). In the globalized era, the meaning system and affirmation are no longer bound to nation or border. It means that membership can be shared throughout the world, and any member can support the development of the other's 'public self,' to affirm the membership of the 'private self.' However, emphasizing conflict on the need of communal (religious) affirmation has an opposite effect to conflict resolution. It will make the existing conflict prone to escalate and provoke anger on the communities who hold the same identity. Added to the conflict dynamics, the religious sentiment raises a challenge to the principle of impartiality and stirs up the paradoxical question of identity. Identity can drive a worldwide solidarity, but it can also put a dividing wall between in-group and out-group. This two sides of the same coin occurred in Indonesia with the dividing views of the Muslim community over the Rohingya humanitarian crisis. The sentiment not only tarnished the humanitarian action but posed a threat to Indonesian multiculturalism.

\section{Methods}

This study uses a qualitative approach to explain the identity aspect in the case of religious sentiment toward the Buddhist community in Indonesia during the Rohingya's refugees crisis that peaked between 2015 and 2017. The design of qualitative method arises due to the necessity that develops during the process of conducting the research (Creswell \& Clark, 
2007). The concepts of identity and solidarity (Luhtanen, 1992; Kastoriano, 2000) will be used as a theoretical frame in understanding how shared identity can construct solidarity toward other groups. The method follows a qualitative procedure on choosing key informants based on consideration of their resourceful insight to the topic and their direct involvement in raising solidarity toward the Rohingya refugees. Data from informants are compared and analysed, and we find that there are two contending practices of solidarity: first, through the conduct of humanitarian act by raising funds to assist the refugees; second, by voicing hatred and the sentiment toward the Buddhist community in Indonesia as a means to show their sympathy for the Rohingya. The later practice describes the values of radical Muslims in dealing with refugees' problems. Lastly, this article also elaborates how the Indonesian government deals with the uproar of the religious sentiment that threatens multiculturalism.

This study follows three procedures or three stages of research: The first is conceptualization research. This stage is crucial to set the direction of the research by studying pre-preliminary data and theories related to the definition of identity and identity conflict. The second stage is data collection. In this stage, we conducted face to face interviews with the primary source and involved directly raising funds and assisting the Rohingya when they arrived in Indonesia. We interviewed representatives from four Muslim communities (Dompet Dhuafa, Al-Imdad, Aksi Cepat Tanggap (ACT), and Pos Kemanusiaan Peduli Umat (PKPU)) and three organizations in charge of dealing with the refugees' problems (SUAKA, UNHCR and IOM). In addition to theinterviews, we also conducted a focus group discussion with government officials (Immigration Officials in Aceh), Muslim communities (komunitas pengajian) which actively raised funds for the Rohingya, and academics (expert on transnational studies from Universitas
Padjadjaran, Dr. Dudy Heryadi and expert of Islamic Studies, Dr. Akim). The discussion is conducted to gather information on how Muslim Indonesia responded to the crisis. The third is data analysis, which is the last stage when data is interpreted to reach conclusion.

\section{Results}

This study outlines the response of Indonesian Muslim communities related to the Rohingya crisis. It appears that while Muslims in Indonesia were involved directly in raising the awareness of solidarity toward the Rohingya, there is a side of identity politics that overshadow the humanitarian act (Hidayat et al., 2017). From an interview conducted by a research team with NGOs involved in the humanitarian assistance for the Rohingya, a positive response are shown in solidarity act, including fundraising, volunteering, and direct distribution of food, clothes and medicine to the victims in Myanmar and to the refugees stranded in Aceh. Muslim organizations, such as Dompet Dhuafa, Aksi Cepat Tanggap (ACT), Al-Imdaad, Pos Kemanusiaan Peduli Umat (PKPU), are among the first organizations that were involved in directly distributing aid to Myanmar. They also built networks with other Non-state Organization (NGOs) in Southeast Asia to coordinate under the platform of Southeast Asia Humanitarian Mission (SEAHUM). ${ }^{2}$ In the focus group discussion, Heryadi, an expert on transnationalism mentioned that "The massive attention illustrates the constructive function of identity that drives solidarity amongst Muslims." This is confirmed by Arif Rahmadi, a representative from Dompet Dhuafa. However, he specified that the pattern of solidarity demonstrated by Indonesia Muslims is diverse: from pengajian ${ }^{3}$,

\footnotetext{
2 Dompet Dhuafa and PKPU are the inisiator of SEAHUM from Indonesia.

3 A general term used to refer to various religious learning and teaching activities (Muhzaki as cited in Dirdjosanjoto, 1999, p. 3)
} 
which collected donations from its members, to students and individual volunteers who took initiative in the streets to collect fundraising. This exemplifies that humanitarian solidarity in Indonesia has formed two levels of interaction: in the transnational framework (build by NGOs) and in societal level (by individual or grassroot initiatives).

Unfortunately, the Rohingya tragedy is used by an Islam extremist group in IndonesiaThe Islamic Defender Front (Front Pembela Islam, FPI) - as agenda to attract followers. They scapegoated Buddhists in Indonesia by accusing them to take part in the atrocities in Myanmar. The religious sentiment showed that despite the capacity as a driving force for humanitarian solidarity, identity can also pose a threat to peace and multiculturalism when it is politicised (Erdianto, 2017). In the narrow sense, identity can create polarization in society. In this context, identity is understood solely in the sphere of "collective pride" and does not function as an instrument for conflict resolution. As Dr. Akim stated in focus group discussion, "The sentiment toward Buddhists during the campaign of anti-Myanmar government in Indonesia showed that religious solidarity and sentiment are two sides to the same coin. It is contradicts the humanitarian principle, also demeaning the act of solidarity." A problem that presents two (paradoxical) sides of identity is outlined the Indonesian Muslim respond towards the Rohingya crisis.

In an attempt to eliminate the religious sentiments and maintain the impartial principles, the Indonesian government coordinated with various elements to establish an interfaith community network. The Humanitarian Alliance of Indonesia-Myanmar (Aliansi Kemanusiaan Indonesia untuk Myanmar, AKIM) consists of various communities, including Mer-C, Indonesia Red Cross (Palang Merah Indonesia), various Islamic organizations such as Nahdatul Ulama (NU) and Muhammadiyah, also the community of Indonesian Buddhist
(Walubi), as well as Catholic and Christian organizations. The alliance has two tasks: to provide humanitarian assistance and to push an appeal to the Myanmar government to take appropriate measures for the conflict resolution. But they also have another role on a domestic level: to softening religious sentiments that culminated in 2017, maintaining impartiality and conducting an inclusive form of humanitarian aid.

\section{Discussion}

The solidarity of the transnational Muslim community becomes a vital part of the process of providing humanitarian aid for victims of the Rohingya crisis. The ASEAN political situation that resulted from abiding the principle of non-intervention set as an obstacle for the organization to take a direct measure to the crisis. ${ }^{4}$ In this stagnant situation, the Muslim communities of Southeast Asia initiated a humanitarian committee: the Southeast Asia Humanitarian Mission (SEAHUM). SEAHUM is established by transnational Muslim organizations in Indonesia, Malaysia and Thailand to tackle human right issues in Southeast Asia. It was initially formed to respond to the Rohingya crisis. Since its inception in 2012, various transnational Muslim communities in Southeast Asia have become members. Dompet Dhuafa, Rumah Zakat, and Aksi Cepat Tanggap (ACT) are representatives of the Muslim community of Indonesia, while IKRAM, HALUAN and Amal Malaysia represent the Muslim community of Malaysia. SEAHUM is also supported by the Muslim community of Thailand who also gave an immediate response to the crisis. SEAHUM is also supported by Muslim organizations from another region, Al-Imdaad, a transnational Muslim communitybased in South Africa, Britain, Australia and

\footnotetext{
${ }^{4}$ As Lee Hsien Loong, Singapore Prime Minister said, the crisis was "a concern for all Asean countries, and yet Asean is not able to intervene to force an outcome" (South China Morning Post, 2018)
} 
Japan. For Muslim organizations in Indonesia, the main function of SEAHUM is to ensure that organizations work hand-in-hand (Hidayat et al., 2017).

Indonesia also took immediate response in dealing with the Rohingya crisis. The shared a belief of Islam, that in the context of Muslim community solidarity plays an important role in encouraging a bond of "brotherhood" to help each other (Ismail, personal communication, 2017). A similar picture can be seen in the support of the Muslim community towards the Palestine issue, which evolves from territorial and political conflict into an unresolved religious issue. The constructive function of identity is depicted in solidarity and in the humanitarian act of Indonesian Muslims communities. It is increasing rapidly since the fishermen of Aceh rescued more than 2,000 Rohingya survivors stranded in severe condition near the Malaka Strait. Arif Rahmadi Haryono, representatif from Dompet Dhuafa (2017), mentioned that diverse circles of Muslim community took up the streets to raise donations for the Rohingya refugees in Aceh. Along with the grassroots and individual volunteer, various nongovernmental organizations also contributed in establishing coordination - both with the Indonesian government and international networks - to assist the victims in Myanmar and refugees in Aceh.

The significant role of Muslim communities was also formed based on identity similarity that develops as essential ramifications for international Muslim solidarity. Kasner (as cited in Kappen, 1995, p. 26) explains that the transnational Islamic movement is established as a platform for cross-national political action, whether in ideas, behavior, or identity levels. However, result from focus group discussion conducted in Universitas Padjadjaran, Jatinangor (2017) shows that there is also another form of Muslim identity movement that operates in the field of humanitarian action. Indonesia has a number of non-state organizations that set a fine example of the humanitarian movement. Malaysia, another Muslim majority in Southeast Asia, also supports the growing numbers of Muslim humanitarian movement. The existence of Muslim humanitarian movement has reconstructed the traditional meaning of Islamic movement. By promoting broad cross-border networks, the transnational Muslim community has defined a new term of transnational Moslem as humanitarian function.

Trust and cooperation operate as the basic formation of transnational Muslim solidarity movement, while identity serves as the core value for goal setting. The combined two concepts link identity to transnational communities. Milani and Laniado (2007) stated that similarity of identity performs as the main force in every transnational social movement (p. 19). It does not only function as a political basis but relates to universal agenda setting of the global problem, such as humanitarian crisis. The emphasis of identity in the setting of universal issues is also reflected in the symbolic transnational movements such as race, sex, nation, or the minority movement. Identity drives individuals to contribute either formally or voluntarily. The massive support of Indonesian Muslims towards the Rohingya has a similar basis. The extensive fundraising action for Rohingya followed by the rampant mass media coverage expressed the strong impulse of the Indonesian Muslim community to respond to the humanitarian crisis in Myanmar. The Muslim communities also encouraged the Indonesian government to take an active role in mediating the conflict. They also supported the government to issue a fundamental change in the Indonesian government's regulation of refugees through Presidential Decree No. 125/2016 on the procedures for handling international refugees. This policy is an important measure for Indonesia as the country has not yet ratified the 1951 International Convention on Refugees. 
However, strong identity ties can be a preeminent obstacle in the efforts of conflict resolution. This means the conflict resolution between ethnicities is almost impossible when the spectrum of sacred identity ties are involved. Emotional bias-embedded in identity conflicthas also contradicted the principle of humanities and become a barrier in the effort for dialogues between conflicting parties. The wide sympathy for the Rohingya expressed by Indonesian Muslims provides valid evidence that identity plays a major emotional tie in promoting solidarity. However, added to the enormous humanitarian support, a crucial issue related to identity ties that tarnished the humanitarian efforts and posed a problem in multicultural Indonesia had arisen.

The problem of religious sentiment arose in 2017, when there was a massive protest staged by Islamic Defenders Front (Front Pembela Islam, FPI) in Borobudur, which is known as the largest Buddhist site in the world. The protesters perceived that the Buddhists in Indonesia were also involved in the repression in Rakhine; therefore, they intended to destroy Borobudur as a symbolic action for their resentment. This perception discloses the critical construction of identity that tends to polarize contending parties into a separate line of "us versus them." The impact was felt deeply when the Buddhist community in Indonesia was given a violent threat and was exploited as the scapegoat for issues in Myanmar. The sentiment over Buddhists has become a shocking experienced for Indonesian Muslims. Extensive exposure of identity to promote solidarity has become a driving force for hatred. The consequence is terrifying: it led to the blind fanaticism that endangers national integrity. The issue of religious sentiment in Indonesia illustrated how the paradox of identities could bring two different response to the Rohingya refugees crisis in Indonesia. The FPI, who instigated the sentiment, are an Islamist intolerance group famous for their sweeping action and founded in 1998. It has thus far been predominantly depicted as a predatory, opportunistic association of thugs, whose interests are more economic than religious (Wilson, 2014).

According to Mietzer and Muhtadi (2018), FPI supporters ranged from middle class

Figure 1.

Percentage of Indonesian Muslims supporting FPI and its agenda

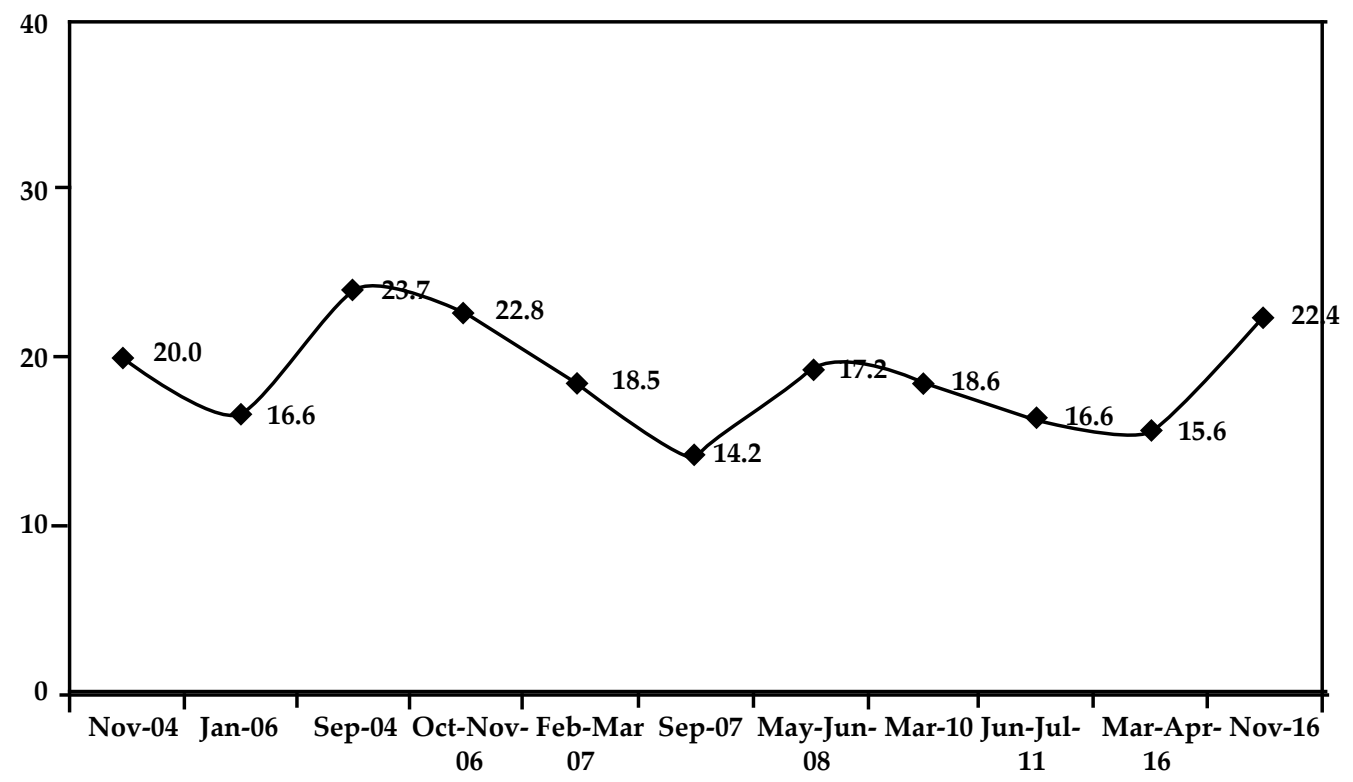

Source: Mietzer and Muhtadi, 2018 
income, to low educated Muslims. Data from the 2016 Lembaga Survey Indonesia (LSI) poll is illustrative in this regard. Among Indonesian Muslims with a tertiary degree, $18.7 \%$ knew and supported FPI, while only $8.2 \%$ of Muslims with an elementary school education (or less) did. The LSI (in Mietzer \& Muftadi, 2018) also provided the Muslims supporting FPI since 2004, as shown in the figure 1.

Data in the figure 1. shows that the percentage of support given by Indonesian Muslim toward the FPI agenda in 2016 has reached the highest point with $22.4 \%$. This number is crucial in explaining the popular anti-Buddhist sentiment in 2017. The FPI's response to the Rohingya crisis has tarnished the humanitarian aspect of the solidarity. The agenda set a fine example of how religious identity can bind a strong emotional feeling of sympathy and solidarity, also capable of driving hatred and sentiment. In dealing with this condition, Muslim organizations such as Dompet Dhuafa, Rumah Zakat, ACT, Nahdatul Ulama (NU), and also Muhammadiyah voiced a clear message of impartiality to various circles of society. Through expanded campaigns and sharing information, they provided an understanding of humanitarian principle and efforts to eliminate the religious sentiment.

$\mathrm{ACT}$, for example, explained that the main goal of the humanitarian solidarity had been "to helping the victims of humanitarian crisis and to bring the victims of conflict to regain their lives, and fulfilling their basic right as human beings in general, regardless of their identity." Mr. Husaini Ismail from ACT Aceh (2017) said, "We also pushed the message of impartiality by voicing their slogan: saving one life means to save the humanity." Dompet Dhuafa also voiced the same message of humanitarian by providing information about the real condition in Myanmar. Arif Rahmadi Haryono from Dompet Dhuafa (2017) mentioned that in its campaign, Dompet Dhuafa explained to the public that the repression was not limited only to the Rohingyas but to other ethnic groups in the state of Arakan; therefore, the humanitarian assistance was not confined only to Rohingya. Volunteers of Dompet Dhuafa involved directly in providing assistance to the victims in Myanmar stated that violence occurred in Rakhine also impacted the lives of society as a whole, including the Buddhist Rakhine community. In this condition, the need for humanitarian assistance is not the privilege of the Rohingya but also other victims of conflicts in Myanmar. The message of impartiality had been pushed on their campaign by supporting all victims affected, regardless of their identity. This was an attempt by Muslim organizations to minimize the misconceptions and blind fanaticism regarding the Rohingyas. Another act of impartiality was also demonstrated by various Muslim communities by establishing interfaith cooperation and coordination in the handling of Rohingya refugees in Indonesia. The coordination involved organizations such as the Wali Buddhist Indonesia (Walubi) and the Indonesian Catholic Church communities.

Yet, the challenge to encourage and maintain the principle of impartiality is not an easy task. This challenge is highlighted during the Focus Group Discussion held in Bandung with the representatives from AKIM and experts of transnationalism, that the efforts of various Muslim communities to promote humanitarian principles conflict with the interest of particular groups who were using the Rohingya issue to increase their political popularity. Consequently, the grassroots level of Muslim communities had been most prone to the provocation. Limited information on the ongoing conflict in Myanmar also developed into a great obstacle for the people to give balance information on the conflict. Facing the danger of horizontal conflicts, the Indonesian government established the Humanitarian Alliance of Indonesia-Myanmar (Aliansi Kemanusiaan Indonesia untuk Myanmar, AKIM). The multi-identity alliance is intended to 
strengthen the coordination of humanitarian actions based on multi religious organizations. AKIM members are diverse-from Palang Merah Indonesia (Indonesian Red Cross), Mer-C to multiple religious organizations. With AKIM as a humanitarian platform, the Indonesian government stated that humanitarian solidarity is not bound by certain identity.

The alliance has been pro-actively conducting double track diplomacy. By providing humanitarian assistance, they also pushed an appeal to the Myanmar government to take appropriate measures for the conflict resolution. In performing their mission, AKIM coordinated with various parties including the Indonesian government, international refugee organizations (IOM and UNHCR), as well as religious leaders in Myanmar. The latter is crucial in understanding the dynamics of the conflict. In carrying their humanitarian mission, AKIM often confronted the bureaucratic problem; therefore, the role of the Indonesian government to sustain relations with Myanmar is very crucial in supporting the role of AKIM's humanitarian diplomatic mission. The task for AKIM in resolving and mediating the conflict in Myanmar still has many challenges. However, it created a foothold for more inclusive humanitarian approach to soften religious sentiments in Indonesia.

\section{Conclusion}

The obstacles faced by ASEAN members have encouraged Muslim communities from various countries to promote solidarity and engage directly in the Myanmar conflict. As a Muslim majority country, Indonesia responded immediately to the crisis and led to a humanitarian movement of various segments of society. Identity ties played the main force for the Muslims in Indonesia to provide humanitarian assistance. The humanitarian act can be described in two main patterns. First, strengthening solidarity in various forms of tabligh; in this form, fundraising was conducted in mosques and in Islamic centers. Second, giving the donation through humanitarian organizations that are trustworthy and have extended networks with other Muslim communities in different countries. Examples are Dompet Dhuafa, ACT, and PKPU. However, solidarity based on identity has been always overshadowed by the adverse impact of fanaticism and emotional bias. The anti-Buddhist sentiment occurred in 2017 is a clear example of how fanaticism over identity could threaten Indonesian multiculturalism.

Nonetheless, identity still plays an important force in generating emotional attachment. Through the bond of identity, the Muslims in Indonesia can continually provide humanitarian assistance to the Rohingya. However, the blind fanaticism of identity could be the main obstacle in carrying the principle of impartiality. The politicization of the Rohingya issue by the FPI that occurred in Indonesia has tarnished the solidarity of humanity. Impartiality that should be the basis of humanitarian action is challenged by identity sentiment. Facing the critical condition, the Indonesian government with various Muslim communities initiated an inclusive network and coordination for humanitarian action. The IndonesiaMyanmar Humanitarian Alliance (AKIM) is established to muffle the religious sentiment by maintaining impartiality in providing assistance to the victims in Myanmar. In outlining the Indonesian Muslims' response to the Rohingya crisis, we confronted the politicization of identity. Identity approach to a social conflict can result a constructive manner, but it also can trigger a sentiment that threatens Indonesian multiculturalism, when it is politicised for the sake of political power. This article, however, is limited to the explanation of the cause of religious sentiment and identity conflict. How to tackle religious sentiment still needs further elaboration. 


\section{References}

Arendshorst, J. (2009). The dilemma of noninterference: Myanmar, Human Rights, and the ASEAN Charter. Northwestern Journal of International Human Rights, 8(1), 102-121.

ASEAN leaders address Myanmar's Rohingya crisis, but refuse to point finger at Aung San Suu Kyi. (2018, March 18). South China Morning Post. Retrieved from https://www.scmp.com/news/asia/ southeast-asia/article/2137712/aseanleaders-address-myanmars-rohingyacrisis-refuse-point.

Basedau, M., Struver, G., Vullers, J., \& Wegenast, T. (2011). Do religious factors impact armed conflict? Empirical evidence from Sub-Saharan Africa. Terrorism and Political Violence, 23(5), 752-779. doi: 10.1080/09546553.2011.619240

BBC Indonesia. (2017). Kekerasan Rohingya: Apa yang harus dilakukan warga Indonesia?. Retrieved from http://www.bbc.com/ indonesia/indonesia-41144847.

BBC Indonesia. (2017). Polisi tetapkan siaga satu di Borobudur hingga Sabtu. Retrieved form https://www.bbc.com/indonesia/indones ia41183998?ocid=socialflow_twitter.

Creswell, J. \& Clark, P. V. (2007). Designing and conducting mixed methods research. California: Sage.

Dirdjosanjoto, P. (1999). Memelihara umat (Kiai Pesantren-Kiai Langgar di Jawa). Yogyakarta: LKIS.

Dozens of Rohingya come ashore in Indonesia. (2018, April 20).The Jakarta Post. Retrieved from http://www.thejakartapost.com/ news/2018/04/20/dozens-of-rohingyacome-ashore-in-indonesia.html.

Erdianto, K. (2017). Jangan lihat isu Rohingya sebagai konflik antara Islam dan Buddha. Retieved from https://nasional.kompas. com/read/2017/09/06/06410621/janganlihat-isu-rohingya-sebagai-konflikantara-islam-dan-budha.
Galtung, J. (1958). Theories of conflict: Definition, dimension, negation and formation. New York: Columbia University Press.

Gelfand, M. J. \& Cai, D. A. (2004). Cultural structuring of the social context of negotiation. In M. J. Gelfand \& J. M. Brett (Eds.), The handbook of negotiation and culture (pp. 238-257). California: Stanford Business Books.

Habibollahi, A., McLean, H., \& Diker, Y. (2013). Crimes against humanity the case of the Rohingya People in Burma (Rep.). Otawa, Canada: The Norman Paterson School of International Affairs.

Hagan, J. \& Rymond-Richmond, W. (2009). Darfur and the crime of Genocide. Cambridge: Cambridge Press.

Hidayat, T., Sari, D. S., \& Pratisti, S. A. (2017). Moving beyond identity-based solidarity: Transnational moslem community engagement toward the Rohingya refugees. Advances in Social Science, Education and Humanities Research, 136(22), 404-409. doi: 10.2991/ icosop-17.2018.63

Hodges, A., \& Rayda, N. (2017). Indonesian Islamists recruiting volunteers for Rohingya jihad. The Australian. Retrieved from https://www.theaustralian.com.au/ f9cd04129233827d4f2ba9f17664d844.

Jati, I. (2017). Comparative study of the roles of ASEAN and the organization of Islamic cooperation in responding to the Rohingya crisis. IKAT: The Indonesian Journal of Southeast Asian Studies, 1(1), 1732. doi: 10.22146/ikat.v1i1.27466

Kappen, T. R. (1995). Structures and international institutions. Cambridge: Cambridge University Press.

Kastoriano, R. (2000). Immigration, transnational communities and citizenship. Journal Revue Internationale des Sciences Sociales, 16(5), 353-358.

Khin, M.Y. (2005). Salience of ethnicity among Burman muslims: A study in identity 
Formation. Intellectual Discourse, 13(2), 161-179.

Kyaw, Y. H., Taylor, R., \& Tin, M. T. (2005). Myanmar: Beyond politics to societal imperatives. Singapore: Institute of Southeast Asian Studies.

Linberg, J. (2008). Running on Faith?. Oslo: Oslo University Press.

Luhtanen, R., \& Crocker, J. (1992). A collective self-esteem scale: Self-evaluation of one's social identity. Personality and Social Psychology Bulletin, 18(1), 302-318. doi: 10.1177/0146167292183006

Martin, M. F., Margesson, R. \& Vaugh, B. (2017). The Rohingya crises in Bangladesh and Burma (Rep.). Washington, USA: Congressional Research Service.

Milani, C., \& Laniado, R. (2007). Transnational social movements and the globalization agenda: A methodological approach based on the analysis of the world social forum. Brazilian Political Science Review, 1(2), 10-39.

Milton, A. H., Rahman, M., Hussain, S., Jindal, C., Choudhury, S., Akter, S., \& Efird, J. T. (2017). Trapped in statelessness: Rohingya refugees in Bangladesh. International Journal of Environmental Research and Public Health, 14(8), 942. doi:10.3390/ ijerph14080942

Raharjo, S. N. I. (2015). Peran identitas agama dalam konflik di Rakhine Myanmar tahun 2012-2013. Jurnal Kajian Wilayah, 6(1), 35-59. doi: 10.14203/jkw.v6i1.68
Ross, J. D. (2002). Promoting human rights. Ethics and International Affairs, 16(2), 27-31. doi: 10.1111/j.1747-7093.2002. tb00393.x

Ross, M.H.(2002). Psychocultural interpretations and dramas: Identity dynamics in ethnic conflict. Political Psychology, 22(1), 157178. doi: 10.1111/0162-895X.00231

Ross, M. C. (2007). Cultural contestation in ethnic conflict. New York: Cambridge University Press.

Seul, J. R. (1999). Ours is the way of God': Religion, identity, and intergroup conflict. Journal of Peace Research, 36(5), 553-569.

Stryker, S., \& Burke, P. J. (2000). The past, present, and future of an identity theory. Social Psychology Quarterly, 63(4), 284-297. doi: 10.2307/2695840

Wilson, C. (2008). Ethno-Religious Violence in Indonesia (From soil to God). London and New York: Routledge.

Wilson, I. (2014). Morality racketeering: Vigilantism and populist Islamic militancy in Indonesia. In K. Teik, V. Hadiz, \& Y. Nakanishi (Eds.). Between dissent and power: The transformation of Islamic politics in the Middle East and Asia. Basingstoke: Palgrave Macmillan.

Wolff, S. (2006). Ethnic conflict: A global perspective. London: Oxford.

Zeitlin, I. M. (1998). Memahami kembali sosiologi, kritik terhadap teori sosiologi kontemporer. Yogyakarta: Gadjah Mada Press. 